\title{
Bulgarians and Bulgaria in the last quarter of the nineteenth century in the publications of Jan Grzegorzewski (culture, population, economy)
}

Outline of content: Jan Grzegorzewski, an outstanding Polish Slavic philologist and Orientalists, made at the turn of the twentieth century several voyages throughout the Balkans. During his trips he made careful and detailed observations of local social, political and economic relations, and publicised the conclusions in several of his books and articles published the end of the nineteenth and early twentieth century. Special place in his research work was occupied by Bulgaria. The purpose of this study is to present the image of this country as seen by Grzegorzewski through the prism of three central themes brought up in his texts: culture, society and economy.

Keywords: Jan Grzegorzewski, Bulgaria, Bulgarian Exarchate, education, agriculture, trade

While embarking on an analysis of the work of Jan Grzegorzewski, it has to be said that he was as fascinating a figure as he remains unfamiliar. Notwithstanding the fact that today he is fairly often numbered among Poland's most distinguished ethnographers, ethnologists, orientalists and specialists in the field of Slavonic studies, his accomplishments are largely unknown to the broader public. In recent decades these questions have been discussed very occasionally in Polish scholarly publications and there are as yet only few articles on the subject. ${ }^{1}$ The results of

${ }^{1}$ See e.g. J. Reychman, "Zasługi Jana Grzegorzewskiego na polu zbliżenia kulturalnego polsko-bułgarskiego", in: Stosunki literackie polsko-bułgarskie, ed. J. Śliziński, Wrocław, 1971; id., "W ośrodkach orientalnych i orientalistycznych Bułgarii", Przegląd Orientalistyczny 1957, no. 1; Z. Klejn, "Polskie stronice w bułgarskiej historii", Mazowieckie Studia Historyczne, 2 (1998); K. Dobosz, "Początki i pierwszy tom Rocznika Orientalistycznego. Przyczynek do dziejów czasopisma”, LingVaria, 7 (2012), no. 2; U. Kaczmarek, “Jan Grzegorzewski - 'pierwszy' polski orientalista”, Sprawy Wschodnie 2002, no. 1; J. Zborowski, "Historia pewnej książki. Wspomnienie o Janie Grzegorzewskim”, Rocznik Podhalański, 5 (1992); J. Tyszkiewicz, “Jan Grzegorzewski 
more in-depth studies have been relatively rarely included in more extensive considerations in the fields of ethnography, oriental studies, and history in particular. ${ }^{2}$ This is undoubtedly a sound reason and a powerful incentive to provide the reader with a presentation of Grzegorzewski, whose close links to Bulgaria lasting for several decades made it possible for him to witness both political events as well as the changes in the broadly understood social life in the region. Addressing this particular topic is all the more justified on account of his fascinating biography, which is in many cases shrouded in mystery. ${ }^{3}$

Jan Grzegorzewski was born in the village of Szulajki in the vicinity of Zvyahel (today: Novohrad-Volynskyi), in the Volyn region, but it is indeed difficult to specify the date of his birth. It is commonly assumed that he was born in the late 1840s, perhaps in 1846 or 1849 . Grzegorzewski himself referred to the latter date in the resume he wrote $c a 1920$, but all attempts at substantiating this claim are doomed to failure as there are no official documents which would allow a proper verification of his date of birth. ${ }^{4}$ Our knowledge of his young age is also very limited. What we do know is that he attended a gymnasium in Zhytomyr, from where he went on to begin his university education in Slavonic studies at the university of Odessa. We cannot say for certain whether he received his degree. However, it is a well-established fact that he travelled widely before the year 1870 when he settled in Galicia. During his travels he visited the Middle East, Asia and northern Africa. ${ }^{5}$ During the Russian-Turkish war of 1877-1878 he served in the Balkans as a war correspondent for the French Le Figaro and for the Polish-language newspapers in Galicia and Congress Poland: Gazeta Codzienna and Gazeta Warszawska. ${ }^{6}$ It is beyond all doubt that it was from that time onward that Grzegorzewski developed

w ostatnich latach życia: 1916-1922”, Almanach Karaimski, 4 (2015); J. Rubacha, "Obraz przemian politycznych w Bułgarii w książce Jana Grzegorzewskiego 'Rok przewrotów. (Bułgarya 1885/6)”, in: Wokót reportażu podróżniczego, ed. D. Rott, Katowice, 2007.

${ }^{2}$ E.g. J. Reychman, Peleryna, ciupaga i znak tajemny, Kraków, 1971; Z. Klejn, Polskie ślady $w$ budowie nowożytnej Bułgarii, Łowicz, 1999; M. Hoszowska, Ludwik Finkel i Akademia Umiejętności. Z dziejów współpracy naukowej Lwowa i Krakowa na przełomie XIX i XX wieku, Rzeszów, 2011.

${ }^{3}$ These issues were raised a number of times; the author (presumably: Andrzej Gawroński) of Grzegorzewski's obituary published in 1925 in the Rocznik Orientalistyczny [Orientalist Yearbook] wrote: 'biographical information about Jan Grzegorzewski is both scanty and uncertain; all we have, at least with regard to his young age before 1876, is derived from a single source: his own stories. And those who knew him were well aware that in these stories the Dichtung und Wahrheit were inextricably linked, so that they could serve as a background for a fascinating novel rather than a strict biography”; Dobosz, Początki i pierwszy tom, pp. 177-178, fn. 1.

${ }^{4}$ Ibid., p. 177.

${ }^{5}$ A result of these journeys was his work: $Z$ pod nieba wschodniego. Nowele i fragmenty podróży, published in Lviv in 1904. For more on this see: A. Chłoniewski, Nieśmiertelni. Fotografie literatów lwowskich, Lwów, 1898, p. 49; M. Kizilov, "Jan Grzegorzewski's Karaite materials in the archive of the Polish Academy of Sciences in Kraków”, Karaite Archives, 1 (2013), p. 60.

${ }^{6}$ Reychman, Peleryna, pp. 9-11. 
an interest in this part of Europe, which in time evolved into fascination. After the war ended, he travelled several times across the Balkans, ${ }^{7}$ particularly in Bulgaria, a country of which he became particularly fond. No wonder then that his first publications were devoted to this country, more specifically to its political, economic and social condition. One should note in particular three articles by him: "Spółczesna Bułgarya" [Contemporary Bulgaria], published in the Warsaw magazine Ateneum in 1883, ${ }^{8}$ and Stosunki handlowe $z$ Bułgarya [Commercial relations with Bulgaria] as well as Szkolnictwo w Bułgaryi [The education system in Bulgaria], both published in Lviv in Przeglad Powszechny in 1887. ${ }^{9}$ Together with Antoni Piotrowski, Grzegorzewski embarked on another journey to Bulgaria in 1885-1886 to witness the dynamic changes in the country and serve as a correspondent for British, French and Polish newspapers. The visit provided him with the material for his work titled Rok przewrotów (Bułgarya 1885/6) ${ }^{10}$ [The year of revolutions: Bulgaria 1885-1886], which he published in Lviv in 1900.

Having returned to Poland in $c a 1890$, he focused his activities on the idea of setting up an academy of commerce in Warsaw, which was supposed to train specialists in commercial relations with the east. In the run-up process he prepared a set of handbooks for the study of Balkan and Middle Eastern languages including Bulgarian, Romanian, Turkish and Persian. ${ }^{11}$ Eventually, the initiative foundered, despite the support of Ludwik Krasiński, one of the wealthiest magnates in Congress Poland and the head of the Warsaw branch of the Society for the Advancement of Russian Industry and Commerce. Despite this failure Grzegorzewski clearly deserves to be numbered among the first exponents who laid the groundwork for co-operation with Balkan countries, particularly with regard to establishing and maintaining close relations with Bulgaria. ${ }^{12}$

At the turn of the nineteenth and twentieth centuries Grzegorzewski became passionate about the idea of creating a research centre focused on the east and an academic journal which would present the results of research, analyses and reports concerning the Orient in the broad sense and the regions inhabited by southern Slavs. ${ }^{13}$ However, at the very outset the initiative was met with a number of problems and did not attract much interest among Polish researchers, who went so far as to say (to quote from Kazimierz Nitsch) that Grzegorzewski

\footnotetext{
7 Grzegorzewski mentioned these travels a number of times in his works, e.g. in: "Spółczesna Bułgarya" and "Albania i Albańczycy".

8 J. Grzegorzewski, "Spółczesna Bułgarya”, Ateneum, 8 (1883), vol. 2, nos. 2-3.

9 J. Grzegorzewski, "Stosunki handlowe z Bułgaryą", Przegląd Powszechny, 4 (1887), no. 1; J.G. [J. Grzegorzewski], "Szkolnictwo w Bułgaryi”, Przegląd Powszechny, 4 (1887), nos. 8, 10, 11.

${ }_{10}$ J. Grzegorzewski, Rok przewrotów (Bułgarya 1885/6), Lwów, 1900.

${ }^{11}$ Dobosz, Początki i pierwszy tom, p. 178.

12 U. Kaczmarek, "Wystawa poświęcona prof. Tadeuszowi S. Grabowskiemu i prof. Janowi Grzegorzewskiemu, Sofia, 24 czerwca 1996”, Etnografia Polska, 41 (1997), nos. 1-2, pp. 259-261.

13 Dobosz, Początki i pierwszy tom, p. 178.
} 
was an "ignorant daydreamer". ${ }^{14}$ As a result, he decided to take the initiative independently. He moved to Sofia in 1904, where two years later he opened the "Hyacinthaeum" Polish Research Station in the East. ${ }^{15}$ Even though the establishment of the station was undoubtedly a significant success and could be viewed as the crowning achievement of his research work by that time (which had already been noticed across Europe), the institution struggled with serious difficulties, particularly financial in nature. ${ }^{16}$ The founder reported that in addition to himself his institution had two clerks and one adjunct researcher on the payroll and housed a library with a collection of manuscripts and numismatic objects. This claim, however, appears to have been unsubstantiated and seems to represent the wishful thinking on the part of Grzegorzewski, ${ }^{17}$ for when he was leaving Sofia in 1915, he was heavily in debt (including the arrears of rent, fuel and electricity). After the First World War, when Bulgarian authorities entered the premises of the inconspicuous station, the only things to be found, as Zbigniew Klejn put it, were a jumble of bric-a-brac, rags, books and some documents. ${ }^{18}$ Nevertheless, the research activities undertaken by Grzegorzewski in Sofia brought significant results. One should note in particular the publication of historical sources: Turkish acts from the Rumelian registers from the time of the siege of Vienna, ${ }^{19}$ Two firmans of [Ottoman] sultans from the eighteenth century. A historical study of Polish-Turkish commercial treaties ${ }^{20}$ and The firman of Sultan Abdulhamid I of the year 1775..$^{21}$ Other notable examples of his work include The Tomb of Władystaw III of Poland [or: of Varna], ${ }^{22}$ Albania and the Albanians ${ }^{23}$ (highly

14 Ibid., p. 179.

15 The primary aim of that institution was to collect, study and publish archival documents related to the "nearest Orient", i.e. the Balkans and Turkey; Stacya naukowa polska na Wschodzie Hyacinthaeum, Warszawa, 1916, p. 1; for more on this see also: J. Reychman, "O wykorzystanie źródeł orientalnych do historii Polski”, Przegląd Historyczny, 58 (1967), no. 2, p. 297; id., Peleryna, p. 40; Klejn, Polskie ślady, pp. 315-316.

${ }_{16}$ Note in particular the work published in 1903 on the Tatar dialect in Galicia and the Karaim language: J. Grzegorzewski, "Ein türk-tatarischer Dialect in Galizien: Vokalharmonie in den entlehnten Wörtern der karaitischen Sprache in Halicz", Sitzungsberichte der Kaiserlichen Akademie der Wissenschaften Philosophisch-Historische Klasse, 146 (1903), Abh. 1.

17 Stacya naukowa, p. 4.

${ }^{18}$ Klejn, Polskie ślady, p. 318.

19 J. Grzegorzewski, Z sydżyllatów rumelijskich epoki wyprawy wiedeńskiej akta tureckie, Lwów, 1912.

${ }^{20}$ J. Grzegorzewski, “Dwa fermany sułtańskie z XVIII w. Zarys historyczny traktatów handlowych Polski z Turcyą”, Rocznik Orientalistyczny 1916-1918.

${ }^{21}$ J. Grzegorzewski, "Ferman sułtana Abdulhamida I z r. 1775”, in: Księga ku uczczeniu prof. Józefa Tretiaka, Lwów, 1913.

22 J. Grzegorzewski, Grób Warneńczyka: badania autentyczności grobu przy 4-tym kilometrze pobojowiska warneńskiego $z$ d. 10-go listopada 1444 r., z 14 załącznikami, Kraków, 1911. It is worth noting that this work sparked a vigorous discussion in the Kraków, Academy of Learning in 1910; Hoszowska, Ludwik Finkel, pp. 89-99.

23 J. Grzegorzewski, Albania i Albańczycy, Lwów, 1914. 
appreciated in the academic circles), and several articles in widely-read journals such as, for instance, Świat Stowiański [The Slavic World] published in Kraków, since $1905 .{ }^{24}$ Having returned to Poland, Grzegorzewski focused mainly on research in linguistics and folklore, ${ }^{25}$ but until his death in 1922 he remained a staunch supporter of the strengthening of Polish-Bulgarian relations. ${ }^{26}$

In his journalistic writings on Bulgaria Grzegorzewski presented the image of the country seen through the prism of his interests which included history, socio-political questions, and broadly understood culture and ethnography. Simultaneously, he often displayed his literary talent by enriching the narrative with a number of legends and anecdotes. These would usually take the form of invented dialogues, which the author confronted with both his own observations made in the region and the contemporary scholarly literature and memoirs. $\mathrm{He}$ often included fragments of folk and patriotic Bulgarian songs. The result was a rich and multi-faceted portrayal of the country; in his writings the author discussed nearly all aspects of social life in Bulgaria.

Any visitor passing through Bulgaria on the eve of the last eastern war would have been struck from the very first moment by the strange phenomenon, so unfamiliar to our societies: there were no beggars, no poets, no illiterate people. Such is the first impression of this nation which is perhaps the oldest among all Slavs in terms of its presence in the Christian culture, but the youngest as regards the theatre of modern political history. ${ }^{27}$

This is the opening paragraph of his work Contemporary Bulgaria. It provides an accurate characteristics of Bulgarian society on the eve of Bulgaria's independence by emphasising the decisive features which contributed to its manifest societal and economic predominance among other Balkan countries at the turn of the nineteenth and twentieth centuries. The process of raising in prominence took merely three decades and elevated Bulgaria to the status of an important and much desired partner for both the neighbouring countries and the European superpowers.

${ }^{24}$ J. G[rzegorzewski], "Echa zjazdu sofijskiego”, Świat Słowiański, 7 (1911), no. 1 (75); id., "Dragan Cankow”, ibid., no. 1 (77); id., "O 'Echa zjazdu sofijskiego”, ibid., no. 1 (78); id., "Stronnictwa bułgarskie za Aleksandra Battenberga”, ibid., no. 2 (80-81); id., "Siedmiomiesięczna walka o samoistność Bułgaryi”, ibid., no. 1 (87); id., "Siedmiomiesięczna walka o samoistność Bułgaryi”, Świat Słowiański, 8 (1912), no. 1 (88); id., "Siedmiomiesięczna walka o samoistność Bułgaryi”, ibid., no. 1 (89); id., "Penczo Sławejkow", ibid., no. 2 (92-93); id., "Stronnictwa bułgarskie po przewrotach", ibid., no. 2 (95); id., "Stronnictwa bułgarskie po przewrotach" [part 2], ibid., no. 2 (96).

25 J. Grzegorzewski, Język Łach-Karaitów. Narzecze południowe (łucko-halickie), Kraków, 1917; id., Na Spiszu. Studya i teksty folklorystyczne, Lwów, 1919. It should be noted that Grzegorzewski was interested in these matters at an earlier stage, as can be seen in his work: $Z$ kresów Połabskich (Kraków, 1885).

${ }^{26}$ Klejn, Polskie ślady, p. 319.

27 Grzegorzewski, Spółczesna Bułgarya, no. 2, p. 201. 
Grzegorzewski witnessed the positive results of this process in 1877, but the process itself dated as far back as the second half of the eighteenth century, a time which saw the increase in the activity of Bulgarian society owing to the so-called national awakening of Bulgaria and the growing urge to fight for independence in both ecclesiastical and national terms. It is beyond all doubt that these profound changes in Bulgarian mentality ${ }^{28}$ were triggered primarily by the two events: 1) a conclusion by Paisius of Hilendar, a monk from Mount Athos, of his book The Slavonic-Bulgarian History of the Nation, the Tsars, Bulgarian Saints and All Bulgarian Events, ${ }^{29}$ in 1762, describing the heyday of the Bulgarian state; ${ }^{30}$ and 2) an activity of Yuriy Venelin, the author of the work The Old and Today's Bulgarians. ${ }^{31}$ In studying these changes, Grzegorzewski identified two main spheres in which they developed. The first of these was the ecclesiastical question, deeply rooted in the idea of establishing the autocephalous Bulgarian Church. The institution of autocephaly was supposed to intensify the effort to crystallise and strengthen the national identity. ${ }^{32}$

In the early years of Turkish dominance over the Balkans Christians were ruthlessly persecuted and their places of worship destroyed on a massive scale. The subsequent intermittent attempts at forcing people to convert to Islam proved ineffective, ${ }^{33}$ and the Sublime Porte finally relented and recognised the existence

28 While referring to the earlier period, Grzegorzewski wrote: "Bulgarians at the time were afraid and ashamed to declare their nationality; when asked who they were they would say that they were Greeks [...]", Grzegorzewski, Spółczesna Bułgarya, no. 2, p. 203.

${ }^{29}$ Grzegorzewski, Spółczesna Bułgarya, no. 2, p. 202; S.J. Czarnowski, Dziennikarstwo słowiańskie i polskie, Kraków, 1895, p. 187. The work by Venelin, Древние и нынешние болгаре в политическом, народописном, историческом и религиозном их отночении к россиянам. Историко-критические изыскания was published in Russia in two volumes in 1829 and 1841 (the second edition appeared in 1856).

30 "Kronika", Świat Słowiański, 8 (1912), no. 1, pp. 555-556; История славеноболгарская, Sofija, 1961, pp. 29-30.

${ }^{31}$ Grzegorzewski, Spółczesna Bułgarya, no. 2, p. 209; W.R. Wegnerowicz, "Odrodzenie Bułgaryi”, Literatura i Sztuka. Dodatek do Dziennika Poznańskiego, 48 (1912); S. Zankow, Die Grundlagung der Vefassung der bulgarischen orthodoxen Kirche, Zürich, 1917, pp. 24-25.

32 Grzegorzewski noted the importance of this question to the national cause: "Bulgaria [...] hemmed in an alien organism, cut off from contact with related peoples, a direct neighbour of the central habitat of the partitioning power, had been exposed to the first line of the continuous cross fire of hostile factors: Turkish, Greek, Romanian and Albanian; without any support from the outside, it has deprived itself of its inner strength of resistance and its refreshing sources, so helpful in the sustaining of the vitality of the nation. Such a helpful power and source could have been the devout religious sentiment and the keen awareness in their own organised national Church”, id., Spółczesna Bułgarya, no. 3, p. 540.

${ }^{33}$ Within the framework of this action, the focus was initially mainly on the various ways of forcing the Bulgarian population to convert to Islam, but these activities have produced results only in the Rhodopes, and even there they were rather limited. The reason for this was the fact that Islamisation affected only the poorly informed shepherd populace, who demonstrated a relatively low degree of social development. Grzegorzewski related his conversation with a Bulgarian 
and activities of the Orthodox Church, which was made manifest in the fact that the competences of millets were constantly broadened. ${ }^{34}$ But from the perspective of Bulgarians these changes were far from being revolutionary. On the contrary, the direct subordination of the Orthodox Church in the Balkans to the Patriarchate in Constantinople ${ }^{35}$ paved the way for the uninhibited Hellenisation of Bulgarian territories. Most of all, the process consisted in appointing Greek clergymen to not only the ecclesiastical offices, but also to other positions of authority in parishes and monasteries, which lay at the foundation of the whole structure (even if they were lacking in adequate theological education, which was often the case). This situation was due to the fact that the new holders of the highest offices, including the pre-eminent position of the patriarch, could be invested only after an appropriate sum of money had been paid to the Turkish authorities, a situation which encouraged trafficking in ecclesiastical offices of the lower ranks. ${ }^{36}$ As a result, such offices were most frequently given to whoever was the highest bidder, rather than to a fitting person with relevant qualifications to serve as a spiritual leader. ${ }^{37}$ The fiscal pressure on the local population considerably increased, ${ }^{38}$ following the attempts to make the locals cover the cost of these practices. At that time the Patriarchate of Constantinople began a full-scale action of ousting the Bulgarian language from the liturgy and from the schools administered by the church (the so-called kiliya schools), which led to a significant decrease in the quality of education and the widespread use of the unfamiliar Greek language during church services ${ }^{39}$ and in

bishop, who said that the Pomaks "speak Slavonic languages and even though they are Muslims they keep the images of Holy Mary and Christ in their houses; even if they do not expel both Greek and Bulgarian Orthodox priests, they are as indifferent to them as to Muslim hodjas", ibid., no. 2, p. 227; he also noted elsewhere: "they are more devout Muslims than the Turks and are more hostile to Christians", J. Grzegorzewski, Za Dunajem (Bułgarya, Serbia, Czarnogóra), Lwów, 1904, p. 100. In the later period, Turkish authorities decided to relocate the nomadic peoples of Caucasus and Asia Minor into Bulgarian territories and supported the settlements of Tatars, expecting that they would quickly assimilate to local communities. However, these efforts did not bring the expected results; C. Jireček, Geschichte der Bulgaren, Praga, 1876, pp. 140-142, 146; “Bułgarya pod jarzmem tureckim”, Niwa, 16 (1887), no. 302, pp. 92-93; A. Bezenšek, Bolgarija in Srbija, Celovec, 1897, p. 41; Grzegorzewski, Spółczesna Bułgarya, no. 2, pp. 220-221.

34 Grzegorzewski, Spółczesna Bułgarya, no. 2, pp. 220-221.

35 T. Sława, "Propaganda unicka w Bułgaryi", Świat Słowiański, 9 (1913), no. 2, p. 725.

${ }^{36}$ In the late sixteenth century the charge for the office of the patriarch was 6,000 ducats, while in the mid-nineteenth century it reached 120,000 ducats; J. Grzegorzewski, Za Dunajem, p. 91; for more on this see also: Jireček, Geschichte der Bulgaren, p. 511.

37 Grzegorzewski, Za Dunajem, pp. 91-93.

38 Grzegorzewski, Spółczesna Bułgarya, no. 2, p. 209.

39 The result of these actions was also a pronounced marginalisation of a small group of clergy of Bulgarian origin. As Grzegorzewski observed: "the then Bulgarian priests, the only teachers to their own nation, were coerced by the Phanariote bishops to do kitchen and stable tasks", ibid., no. 2 , p. 206 , no. 3 , p. 543 . 
some sections of Bulgarian society, particularly in cities. ${ }^{40}$ One other important result of Hellenisation was a peculiar discrepancy: on the one hand, social attitudes expressed the growing distance between the people and the Orthodox Church, scepticism about religion, and far-reaching tolerance for a variety of opinions on life. On the other, there persisted the sentiment regarding the remarkably important role of religion in creating and strengthening the national identity. To quote from Grzegorzewski:

Bulgarians are attached to their faith and religious practice; it could not be otherwise, for it is largely due to this practice that the national identity can be preserved from being utterly obliterated. And yet, they are far from fanaticism or hostility towards other religions. Indeed, it is not rare for them to live under one roof with the heterodox or to be on friendly terms with Muslims [...]. ${ }^{41}$

This ambivalence, however, did not hinder the efforts of the local Orthodox Church aimed at becoming independent from the Greek patriarchate. In the wake of the growing discontent of the Bulgarian society, the first actions in this field were taken in the mid-1840s, but initially they did not bring the expected results. ${ }^{42}$ But people remained ready for renewed actions - the proclamation of the hatt-i-humayun of 1856, the decree of the sultan announcing religious tolerance and freedom of belief in Turkey, was an opportune moment. Two years later the Sublime Porte convened an ecumenical council, which, however, due to the objections of the patriarch of Constantinople, did not take decisions to satisfy the demands of the Bulgarian people, who insisted that all local ecclesiastical provinces should be presided over by Bulgarians. ${ }^{43}$ The discontent was festering and it culminated in 1860: during Easter service the leader of Bulgarian movement, Ilarion Makariopolski, intentionally did not mention the name of the Patriarch of Constantinople in the prayers, which was an ostentatious gesture of severing the relations with the patriarchate. ${ }^{44}$ As this unilateral decision posed a serious threat to the internal affairs of the state, the Sublime Porte forced the patriarch to give his consent to further negotiations

40 The Hellenising actions undertaken by the Greek ecclesiastical authorities also took the form of destroying historical and literary heritage of Bulgaria; many precious books, manuscripts, memoirs and pamphlets were destroyed in the process; ibid., no. 2, p. 210; Grzegorzewski, Za Dunajem, p. 93.

41 Grzegorzewski, Spółczesna Bułgarya, no. 2, p. 213; see also id., Za Dunajem, p. 178.

42 These activities were marshalled by two prominent national activists: the later bishop of Tarnovo, Ilarion Makariopolski, and the monk of Mount Athos, Neofit Bozveli of Hilandar; S. Zankow, Die Grundlagung der Vefassung der bulgarischen orthodoxen Kirche, Zürich, 1917, pp. 27-28. Both clerics were imprisoned and later relocated to Mount Athos. Neofit died in detention in 1848, while Ilarion was released in 1850 .

43 Grzegorzewski, Spółczesna Bułgarya, no. 2, p. 209.

${ }^{44}$ Grzegorzewski, Za Dunajem, p. 157; Zankow, Die Grundlagung, pp. 27-28. For this offence he was arrested by Turkish authorities and in 1861 sent into exile in the Turkish hinterland, where he stayed until 1864. 
concerning the autonomy of the ecclesiastical province of Bulgaria. The negotiations continued in 1863-1870, but they did not lead to reaching any agreement, owing to the intransigent attitudes of both parties. ${ }^{45}$ Over that time, the social discontent was still on the increase, which called for an intervention of Turkish authorities. "Following the example of bishop Ilarion and the pressures from the people, the Bulgarian clergy left out the name of the patriarch during public prayers and mentioned in its stead the name of the sultan; the parishes refrained from paying for the maintenance of Phanariote clergymen, some of whom were mugged and had to resign their offices" ${ }^{36}$ - the Sublime Porte, fearing that the situation could deteriorate and develop into an open conflict, decided to intervene: on 28 February 1870 Sultan Abdülaziz issued the firman ${ }^{47}$ sanctioning the independence of the Bulgarian Orthodox Church and the institution of the exarchate. ${ }^{48}$

Grzegorzewski noted that the Bulgarian press, which grew dynamically since the mid-nineteenth century, played a vital role in the struggle for ecclesiastical independence: "the nation was downhearted and dispirited; initially, it was unaware of its rights. Later on, it did not dare to voice its discontent, knowing that this voice would be ignored and that others refrained from voicing their own concerns $[\ldots .$.$] . There were local periodicals which made it possible for these questions$ to be discussed publicly and openly" ${ }^{49}$

Thus the press assumed the role of an important cultural factor, which ultimately contributed to the fostering of national awareness. Liuboslovie (Philology), Bulgaria's first periodical, was published in Izmir in 1842 and 1844-1846, edited by Konstantin Fotinov. ${ }^{50}$ Its character was largely encyclopaedic, as it was richly

45 Sława, Propaganda unicka, p. 726.

${ }^{46}$ Grzegorzewski, Spółczesna Bułgarya, no. 2, p. 209; see also: J. Hołubowicz, Bułgarya, jej przeszłość dziejowa $i$ jej obecne narodowe i religijne odrodzenie, Kraków, 1885, p. 61; "Kronika", Świat Słowiański, 7 (1911), no. 1, p. 403.

47 The text of the document can be found in: J. Rubacha, A. Malinowski, A. Giza, Historia Bułgarii 1870-1915. Materiały źródłowe z komentarzami, Warszawa, 2004, pp. 15-17.

48 Grzegorzewski, Spółczesna Bułgarya, no. 2, p. 209; Jireček, Geschichte der Bulgaren, p. 236; Bułgarya pod jarzmem, no. 302, p. 945; C. Jankowski, Na gruzach Turcji. Zarysy polityczno-publicystyczne, Warszawa, 1915, p. 46; A. Miecznik, Macedonja i Macedończycy, Warszawa, 1904, p. 98; Czarnowski, Dziennikarstwo stowiańskie, p. 190. One should note that the strife continued, which led to the act of excommunication issued by the Patriarch of Constantinople against the Exarchate on 14 September 1872 (Grzegorzewski, Spółczesna Bułgarya, no. 2, p. 213); it was abolished only in 1909; see also: Sława, Propaganda unicka, p. 728; Jireček, Geschichte der Bulgaren, p. 236. It should also be noted that the establishment of the Exarchate had an indirect impact on the transformation of the dispute which had been almost exclusively limited to ecclesiastical affairs into a bitter conflict of political nature. It affected the Bulgarian-Greek relations, especially after 1878, and exacerbated the struggle waged by both countries over the zones of influence in Macedonia, a situation which lasted continuously until the outbreak of the Balkan wars in 1912.

49 Grzegorzewski, Spółczesna Bułgarya, no. 2, p. 210.

${ }^{50}$ Ibid., p. 211; id., Za Dunajem, p. 155; "Kronika”, Świat Słowiański, 7 (1911), no. 1, p. 80; Wegnerowicz, Odrodzenie Bułgaryi; Czarnowski, Dziennikarstwo słowiańskie, pp. 187-188. 
illustrated and was composed of articles on history, the Bulgarian language and geography as well as texts aimed at bettering the morals. The main goal of the authors was to develop the national awareness of Bulgarians. At about the same time, Ivan Bogorov edited a short-lived periodical Bylgarski Orel in Leipzig, which was discontinued after only a few issues in 1847 . The editor, however, was not discouraged and two years later founded another political-literary periodical Carigradski Vestnik, ${ }^{51}$ which was published continually in Constantinople for thirteen years. In addition to journalistic essays, the periodical contained articles about geography and history, biographical pieces about famous people and literary texts. The journal provided ample space for numerous debuting writers, including the poet and composer Dobri Chintulov and Petro Slaveikov, a poet, folklorist, political activist, who later on held the office of a minister. The authors writing for the journal took part in the debate on the possibility of the union between the Orthodox and the Catholic Church, which was taking place in the early 1860s. The circle of this periodical condemned the idea of seeking communion with Rome, as opposed to the group centred around the journal Bulgaria founded in 1859 by Dragan Tsankov. ${ }^{52}$

As it has been already noted, the press played a vital role in the struggle for the independence of the Bulgarian Orthodox Church from the authority of the Greek patriarchate. The number of periodicals increased considerably at that time. In the years 1858-1862, Dimityr Mutev founded the highly popular journal Bulgarski Knizhnici in Constantinople; it was later edited by I. Bogorov, Gavrilo Krestovich and Todor Burmov among others. ${ }^{53}$ The journal was published under the auspices of the Bulgarian Reading Room ${ }^{54}$ in the capital and discussed primarily historical, social and political issues. The readers appreciated especially the texts on the Church, Slavonic studies, linguistics and education in the broad sense. One other important journal which was taking part in the ongoing debate was Turciya edited by Nikola Genovich ${ }^{55}$ since 1862 . The émigré press was also actively involved in fostering national awareness. The year 1860 saw the foundation of the journal Bratski Trud in Moscow. ${ }^{56}$ It was created by a group of students led by

${ }^{51}$ Grzegorzewski, Spółczesna Bułgarya, no. 2, p. 211; Wegnerowicz, Odrodzenie Bułgaryi.

${ }^{52}$ Grzegorzewski, Spółczesna Bułgarya, no. 2, p. 211; “Kronika”, Świat Słowiański, 7 (1911), no. 1, p. 80; Czarnowski, Dziennikarstwo słowiańskie, p. 188.

53 Grzegorzewski, Spółczesna Bułgarya, no. 2, p. 211; Czarnowski, Dziennikarstwo słowiańskie, p. 188.

54 T. Sopodźko, "O czasopismach w Bułgaryi", Przegląd Powszechny, 8 (1891), no. 29, p. 436. The Bulgarian Reading Room played a vital role in the life of Bulgarian diaspora in Constantinople. Its educational activities included providing access to periodicals published in Turkey in the Bulgarian language, issuing publications, leading outreach campaigns, theatre and charitable work.

55 Czarnowski, Dziennikarstwo słowiańskie, pp. 188-189; Grzegorzewski, Spółczesna Bułgarya, no. 2, p. 211.

56 Grzegorzewski, Spółczesna Bułgarya, no. 2, p. 211; Czarnowski, Dziennikarstwo słowiańskie, p. 188. 
Konstantin Miladinov and edited by Rayko Zhinzifov. One should also note two periodicals edited by Georgi Rakovski: Dunavski Lebed ${ }^{57}$ in Belgrade and, since 1864, Bydeshtnost in Bucharest. Other popular journals published in Romania at about that time included Svoboda (edited by Luben Karavelov), Ivan Kasabov's Narodnost and Nezavisimost, the conservative daily newspaper Otchestvo, Gayda (founded in Constantinople by Petko Slaveikov), Makedonia (a journal of political satire, devoted primarily to the case of the Bulgarians in Macedonia) ${ }^{58}$ and Zornitsa, run by the American Biblical Society, ${ }^{59}$ first as a monthly and later a weekly magazine, which published the texts of all most prominent activists of the national movement. ${ }^{60}$

Given the context of the struggle for the independence of the Bulgarian Orthodox Church, one has to discuss the aforementioned idea of abandoning the supremacy of the patriarch in Constantinople and entering into communion with Rome, an idea which was supported by some political activists in Bulgaria and presented by Grzegorzewski in his writings. ${ }^{61}$

In 1860 the Bulgarian Orthodox Church ostentatiously severed the links with Constantinople. In late December of the same year, in the face of the indulgent attitude of the Sublime Porte towards the festering conflict, a group of politically involved Bulgarians residing in the capital sought to contact the papal legate in Istanbul archbishop Paulus Brunoni. ${ }^{62}$ Since the idea of entering into communion with Rome was in line with the Vatican's raison d'état, a special Bulgarian delegation headed by Dragan Tsankov set out to pope Pius IX with their plea for creating a Catholic ecclesiastical province in Bulgaria which would continue the Byzantine traditions of worship and preserve the Old Bulgarian as the language of liturgy. ${ }^{63}$ The result was positive: on 21 January 1861 the pope promulgated the institution of the Catholic (Uniate) Bulgarian Church, which was followed in mid-April by the

57 Grzegorzewski, Spółczesna Bułgarya, no. 2, p. 211.

58 As Grzegorzewski noted, the periodical: "was edited with extraordinary talent and for the most part dedicated to the cause of Macedonian Bulgarians; to this end, the editors made allowances for the preferences of the inhabitants and published texts written in Greek or in the Macedonian parlance written with Greek characters", ibid., no. 2, pp. 211-212.

59 R.J. More, Under the Balkans. Notes of a Visit to the District of Philippopolis in 1876 - Primary Source Edition, London, 1877, pp. 41-43.

${ }^{60}$ Grzegorzewski, Spółczesna Bułgarya, no. 2, p. 211, "Kronika”, Świat Słowiański, 7 (1911), no. 1, p. 80, Czarnowski, Dziennikarstwo słowiańskie, pp. 189-190. Periodicals founded in the 1870 also had considerable merit in the strengthening of the national spirit; from these Grzegorzewski mentioned the periodicals published in Constantinople (Napredyk, Vek and Den), Adrianople (Odrin), Ruse (Dunaw) and Bucharest (Znamie, Nezavisimost and Swoboda), Grzegorzewski, Spółczesna Bułgarya, no. 2, pp. 211-212, fn. 2.

${ }^{61}$ Grzegorzewski, Spółczesna Bułgarya, no. 2, p. 213; id., "Dragan Cankow”, Świat Słowiański, 7 (1911), no. 1, pp. 356-357; id., Za Dunajem, pp. 157-158.

62 Hołubowicz, Bułgarya, p. 61.

${ }^{63}$ Grzegorzewski, Za Dunajem, p. 158. 
consecration of archbishop Józef Sokolski as its superior. ${ }^{64}$ The idea of establishing the independent Bulgarian province under papal jurisdiction not only met with the opposition of the patriarch in Constantinople, who hastened to petition the Turkish authorities to prevent this from happening (which only exacerbated the already bitter controversy), but also stirred up a serious disturbance in the Bulgarian national movement. Its members became involved in heated disputes lasting several month ${ }^{65}$ which toned down only after 18 June 1861 when archbishop Sokolski went missing in mysterious circumstances (the unofficial accusations placed the blame on both the Greeks and the Russians who opposed the idea of the union with Rome). ${ }^{66}$

As a result, the province came to be supervised by the papal legate in Constantinople, which considerably impeded the process of establishing its structures. In order to give it a new impetus, the pope decided to entrust this task to the Congregation of the Resurrection of Our Lord Jesus Christ, commonly known as Resurrectionists, a religious order whose members were of predominantly Polish origin. Karol Kaczanowski, who arrived in Adrianople in 1863, wasted no time and built a school and a chapel, which were supposed to serve as the starting point for further development of ecclesiastical structures. ${ }^{67}$ At about the same time, another school was set up in Plovdiv. Despite the considerable effort of the Resurrectionists, the results were hardly impressive. ${ }^{68}$ In 1865 in the Vilayet of Adrianople the Church numbered about seven hundred people, while the two schools had merely several dozen pupils. ${ }^{69}$ The situation changed only very slightly with the consecration of the new superior of the Church, bishop Rafal Popov. The number of the faithful grew slowly, ${ }^{70}$ which was undoubtedly due to one fact in particular: as Rev. Józef Hołubowicz rightly observed, the background to the idea of the union with Rome was "rather political than religious in character". ${ }^{71}$ Thus it came as no surprise that as the conflict with the patriarchate grew worse, the spread of the Uniate

${ }^{64}$ Ibid., p. 158; Sława, Propaganda unicka, p. 727; Bułgarya pod jarzmem, no. 302, p. 97. The Uniate Bulgarian Church was officially recognised by the Sublime Porte on 9 June 1861.

${ }^{65}$ Grzegorzewski, Dragan Cankow, p. 357; Bułgarya pod jarzmem, no. 302, pp. 97-98; Hołubowicz, Bułgarya, p. 69.

${ }^{66}$ J. Grzegorzewski, Za Dunajem, p. 159; Sława, Propaganda unicka, p. 727; Bułgarya pod jarzmem, no. 302, p. 98; Hołubowicz, Bułgarya, pp. 67-68. See also: В. Каравълчев, “Холмската мисия на Йосиф Соколски и краят на Брест-литовската уния”, Християнство и култура, 9 (2011), pp. 134-142, В. Каравълчев, “Холмската мисия на Йосиф Соколски и краят на Брестлитовската уния”, Християнство и култура, 7 (2011), pp. 124-131.

${ }^{67}$ Grzegorzewski, Za Dunajem, p. 160; Klejn, Polskie ślady, p. 291.

68 "Przegląd prasy słowiańskiej", Świat Słowiański, 7 (1911), no. 1, pp. 145-146.

${ }^{69}$ Hołubowicz, Bułgarya, pp. 72-73, 74. The activities undertaken in the Macedonian territories by the so-called Lazarists (i.e. the Congregation of the Mission) were far more successful. In 1863 the Uniate Church in the vicinity of Monastir gathered about 20 villages and 2,000 people.

${ }^{70}$ It is estimated that in the late 1870 there were about 14,000 Uniates in Bulgaria and Thrace and about 17,000 in Macedonia; Sława, Propaganda unicka, p. 727.

${ }^{71}$ Hołubowicz, Bułgarya, p. 79; see also: Sława, Propaganda unicka, p. 726; Hołubowicz, Bułgarya, p. 227. 
ideology considerably declined; finally, the Uniate community played only a marginal role in the newly revived Bulgarian state, where the Orthodox Church received the status of the established religion sanctioned by the Tarnovo Constitution. ${ }^{72}$

Let us now turn to education, another sphere of profound changes in Bulgarian society which Grzegorzewski discussed in his writings. Education in Bulgaria developed together with the crystallisation of the idea of national revival, was directly influenced by the establishment of the Exarchate of Bulgaria in 1870, and had an indirect impact also on other spheres of social life. ${ }^{73}$

The changes in the ecclesiastical administration introduced in the second half of the eighteenth century together with the rampant Hellenisation of Bulgarian territories caused ever more widespread discontent among Bulgarians, who were sceptical about the idea of replacing the Bulgarian language with Greek, not only in churches, but also in the few schools administered by the Orthodox Church, in urban and rural areas alike. ${ }^{74}$ From the late 1820 s onwards, this grassroots passive resistance was supported by the Bulgarian émigré community in the southern territories of Russia. Owing to the benevolence of Russian authorities, Bulgarian expatriates could receive their education at educational institutions established to cater for their needs, a phenomenon taking place on a massive scale. These institutions fostered national awareness, but even more importantly they provided instruction in the Bulgarian language. ${ }^{75}$ Their graduates, inspired by the example of Yuriy Venelin, ${ }^{76}$ ever more often advocated the idea of establishing similar schools in Bulgarian territories. Their initiative led to the establishment of the first Bulgarian school in Gabrovo in $1835 .{ }^{77}$ Soon after that, there emerged a network of small educational institutions independent from the Greek patriarchate. ${ }^{78}$ The books in Bulgarian used as basic teaching aids in these schools were

72 Jireček, Geschichte der Bulgaren, p. 243.

73 These processes were so closely interlocked that, as Grzegorzewski noted, "one can say that the history of the rebirth of Bulgarian nationality in the nineteenth century is the history of Bulgarian education"; J.G. [J. Grzegorzewski], Szkolnictwo, no. 8, p. 306.

${ }^{74}$ It is worth noting that this resistance was much greater in the countryside, and, as Father J. Hołubowicz wrote, it was the rural population "who despite being greatly oppressed and persecuted defeated the fierceness of the enemies with their patience and saved their native language and the rudiments of national life", Hołubowicz, Bułgarya, p. 58.

75 Ibid., p. 59.

76 As Grzegorzewski rightly observed, the work by Venelin, The old and today's Bulgarians, and his views "made him famous and widely read on both sides of the Danube, while the idea of the national revival discussed by him had an impact on his contemporaries; this impact was all the greater that it made itself evident in its immediate and direct implementation in practice, a practice that was perceptible, tangible and expressed in numbers", Grzegorzewski, Spółczesna Bułgarya, no. 2, p. 203; see also: id., Za Dunajem, p. 155.

77 Grzegorzewski, Spółczesna Bułgarya, no. 2, p. 203; J.G. [J. Grzegorzewski], Szkolnictwo, no. 8, p. 306.

78 Grzegorzewski, Spółczesna Bułgarya, no. 2, p. 204; id., Za Dunajem, p. 155. Establishing these schools was possible owing to the passivity of Turkish authorities who were not concerned about Bulgarian education. "It was possible to establish schools provided that the buildings on the 
printed in Russia, Romania, Austria and Serbia. ${ }^{79}$ Initially, this process was developing at a slow pace, but it gathered considerable speed in the late 1850s owing to the financial support from the émigré communities and foreign (mainly Russian) charities. The process was further aided by the appeals to local communities, who were encouraged to participate in the costs of maintaining these educational institutions. ${ }^{80}$ Their support made it possible to make an attempt at bestowing the status of six-grade secondary schools on the schools in Gabrovo an Plovdiv ${ }^{81}$ as well as to increase the number of primary schools ${ }^{82}$ which were supervised by the Bulgarian exarchate. The curricula of these schools were aligned to a common standard with the intention of making the graduates well-equipped for studying abroad at various institutions of higher education. Despite the odds, the number of Bulgarian schools grew steadily and by the mid-1870s such schools could be found in most Bulgarian cities and villages. To quote from Jan Grzegorzewski: "A traveller passing by a Bulgarian village [...] did not need to ask its inhabitants whether they had a school, or whether the pupils attended the classes. Instead, he should have asked how many schools they had or how many pupils were studying there, for there was not a hamlet which did not have a school; if there were 50 cottages or so, a school building was indeed a necessity". ${ }^{83}$ As a result, the level of literacy among the Bulgarians was rapidly increasing, while the access to literature and to the press had a considerable impact on the broadening of horizons and the development of national awareness. ${ }^{84}$

outside did not manifest its character of educational institutions for the infidels in an ostentatious manner, much in the same way as it was with places of worship", J.G. [J. Grzegorzewski], Szkolnictwo, no. 8, pp. 306-307.

79 Jireček, Geschichte der Bulgaren, p. 243.

80 As Grzegorzewski wrote: ‘being indifferent, the Padishah's government did not contribute at all to the maintenance of Bulgarian schools; the burden of the upkeep lay exclusively on the society - on every single commune", J.G. [J. Grzegorzewski], Szkolnictwo, no. 8, p. 307.

${ }^{81}$ In the later period, similar establishments were created in other places. The curriculum of these schools included the Bulgarian language, history, arithmetic and algebra, geometry, natural sciences, rhetoric and foreign languages - primarily Turkish, French or German and Old Bulgarian; More, Under the Balkans, pp. 29-30.

82 These schools taught reading, writing and rudimentary arithmetic; the instruction lasted one year with six hours of classes per day. The cost of maintaining the school and the teacher's salary, which was within the range of 1,000-1,500 Turkish piastres or an equivalent in grain, was covered by the commune; ibid., p. 28.

83 Grzegorzewski, Spółczesna Bułgarya, no. 2, p. 204; see also: Р. Манафова, “Културното развитие на България при временното руско управление (1877-1879), in: Известия на Института за история, т. 29: Из историята на българската наука, просвета и култура през ХІХ u XX в., 1986, p. 289.

84 The accomplishments of Bulgarians in their fight against illiteracy were widely recognised not only in the region, but in the whole of Europe. In the final years of the nineteenth century the illiteracy rate was on average about $45 \%$, as opposed to Montenegro - $94 \%$, Serbia $-75 \%$, Croatia - 67\% ("Kronika", Świat Słowiański, 9 [1913], no. 1, p. 194), and the Polish territories in Galicia and Congress Poland - over $80 \%$. 
The efforts initiated before the regaining of independence gathered even greater momentum after 1878. Under the interim Russian administration measures were taken to speed up the process of reopening the educational institutions which were closed during the war. The hitherto spontaneous development took the form of more concerted and organised actions, which were carried out under the supervision of Marin Drinov. The results were soon evident: at the turn of the years 1878-1879 there were 1,088 popular schools in the Principality of Bulgaria catering for the total number of nearly 48,500 pupils. ${ }^{85}$ This phenomenon went hand in hand with the efforts on the part of Bulgarian politicians to ensure a prominent place for the issue of education in the legislative acts regulating social life in the country. Article 78 of the Tarnovo Constitution stipulated that the Bulgarian state shall provide free of charge and obligatory public education at the primary level. ${ }^{86}$ These constitutional regulations were supervised by the Ministry of Public Education on the level of central government and locally by educational inspectors. The latter often struggled against tremendous odds, particularly in the first years of independence, which resulted primarily from the economic condition of the state at that time. ${ }^{87}$ Nevertheless, there was a keen awareness of the importance of education for social life. This observation is confirmed in the account of Grzegorzewski: "It is expected of elementary schools to go beyond classroom instruction and provide a suitable upbringing. The lecturing and discipline are supposed to instil in children a sense of honour, love of country, and industriousness; it has to teach them to be tidy, orderly and well-mannered". ${ }^{88}$ As a result of these efforts, in spite of difficulties, the number of educational institutions rose to 1,365 by 1881 . The dearth of pedagogical staff was acutely problematic, since after the regaining of independence teachers sought better paid positions in the administration of the state. ${ }^{89}$ This tendency was a serious threat to the system of education, which could in effect have become totally paralysed. In order to mitigate the situation, the process of pedagogical training was considerably simplified: the mandatory period of preparation for aspiring teachers took the form of courses lasting from only six

${ }^{85}$ Jireček, Geschichte der Bulgaren, p. 247. In Eastern Rumelia there were at the time 346 Bulgarian popular schools (with over 48,000 pupils) and 17 secondary schools (with ca 2,000 pupils). The issues concerning education in the province were supervised by the directors of public education at the office of the General Governor; the supervision was exercised locally by 50 inspectors, one per each school district, J.G. [J. Grzegorzewski], Szkolnictwo, no. 10, p. 170, 171; Z. Przesmycki, "Rumelia Wschodnia", Ateneum, 10 (1885), no. 4, pp. 259-260.

86 J.G. [J. Grzegorzewski], Szkolnictwo, no. 8, pp. 307, 309.

87 Grzegorzewski wrote: "the position of such inspectors was one of the most respectable and demanding; it can be hardly compared to similar positions in other countries. It can be fully appreciated only by taking into account the exceptional situation of schools in the newly established state, where everything had to be built up: from books and benches to funding and teaching personnel”, ibid., p. 308.

${ }^{88}$ Ibid., no. 8, p. 310.

${ }^{89}$ Ibid., p. 172. 
to eight weeks. ${ }^{90}$ This offer was addressed primarily to young people. As a result, the level of education among teachers markedly deteriorated, but the number of pedagogues rose from 1,379 in 1879 to 1,760 in $1881 .{ }^{91}$ At the same time efforts were made to attract teachers from abroad. In addition to that, the most talented pupils were being sent to study at various institutions of higher education across Europe owing to a special scholarship scheme. ${ }^{92}$ The Bulgarian authorities strove to correlate the financial needs with the capabilities of the state. With a view to relieving the fairly modest budget available at that time, the system of providing funding and maintenance for schools operative under Turkish occupation was retained in place. Thus, it was still a responsibility of the communes to allocate funds for the adaptation, furnishing and maintenance of school buildings and securing salaries for teachers. The state, as we read in Grzegorzewski's account, "retained only the right to control and provided, so to speak, spiritual succour in the form of pedagogical training for teachers and the indispensable teaching materials such as, among others, the handbooks for use in the classroom". ${ }^{93}$ The communal funds designated for education expenses were drawn from two sources. The first of these was supplied by obligatory contributions paid by all inhabitants, while the other source consisted of two thirds of the income obtained from the selling of candles in Orthodox churches. The budget was occasionally supplied with private donations in cash or in kind (e.g. in grain or wine), as well as with bequests, which for the most part were in the form of money. Real estate was also bequeathed to schools; occasionally, educational institutions were also given a right to the usufruct of the land allocated from the state-owned property, lent for use by private individuals, or from the plots of land designated by the communes. In some communes, the schools had at their disposal acreages exceeding well over 50 hectares, including arable land, pastures and forests, and "equipped" with inns, shops, mills, bakeries, etc. ${ }^{94}$

In the early years after the regaining of independence, the structure of Bulgarian system of education could be seen as composed of three groups. The first of these, and the most numerous of all, was composed of elementary communal schools,

90 Ibid., p. 173. Similar courses were also organized in Eastern Rumelia.

${ }^{91}$ Jireček, Geschichte der Bulgaren, p. 247. At the same time, measures were taken to lay the groundwork for pedagogical training. "Four-year schools were changed into teachers' seminaries. In 1880/81 a temporary pedagogical course was opened in Shumen, and a permanent one in the following year (the duration of the course was one year); one other such course was opened in Vratsa”, J.G. [J. Grzegorzewski], Szkolnictwo, no. 10, p. 173.

92 Ibid., no. 8, p. 310. This programme was aimed at training teachers, but also other specialists: medical doctors, architects, artists, etc.

${ }^{93}$ Ibid., no. 8, p. 310. However, it is worth noting that poor communes could count on the support from the state. This support consisted in both the transfer of state-owned buildings or materials required for their construction, as well as loans and subsidies for the equipment and teaching aids.

94 J.G. [J. Grzegorzewski], Szkolnictwo, . no. 8, pp. 311-312. 
where the curriculum was unified and established by the state ${ }^{95}$; the tuition was free of charge. ${ }^{96}$ The second group consisted of private schools, particularly widespread in Eastern Rumelia, opened on the initiative of ethnic minorities (such as Jews, Turks, Greeks or Armenians) of funded by heterodox communities (note the Catholic gymnasia in Plovdiv and Adrianople or the Protestant schools in Samkovo and Plovdiv). The third group included the state-run schools, i.e. the gymnasia, which provided education at the secondary level, and the specialised schools such as technical colleges, agricultural schools and seminaries. Before 1877, there had been only three schools of the latter type in Bulgarian territories, but over the course of only five years their number rose to 13 in the Principality of Bulgaria and 32 in Eastern Rumelia. ${ }^{97}$

The attempts at enforcing compulsory attendance at schools were an important element of educational policy at the time. The Bulgarian society en masse recognised the benefits of education ${ }^{98}$ and was keen to support the development of the system of education. There were, however, exceptions to this rule as can be seen in the following example noted by Grzegorzewski: "In a certain village in the Kyustendil province, it so happened that when an inspector opened the school, the peasants hid their children in cottages. The mothers of those children who were eventually taken to the school were tearing their hair out and vilified the perpetrators who had the school set up" ${ }^{99}$ Even though such cases were relatively rare, the average school attendance was in the range of $50 \%$ to $70 \%$, so the introduction of compulsory education seemed entirely justified. However, the state authorities had to take into account the local customs and distinctive regional features. For this reason the schools in towns and villages were allowed to differ in terms of the duration of the school year, ${ }^{100}$ while the penalties for infringements of the relevant regulations were small and relatively rarely imposed. ${ }^{101}$

95 This group was supplemented by the communal secondary schools (two-, three-, and even fivegrade), which depended financially on the communes, but were characterized by various curricula, tailored to the local needs and available funding; ibid., p. 309.

96 Elementary education lasted four years, with 25 hours of school per week, and included classes in religion, the Bulgarian language, rudiments of natural sciences, geography and national history, mathematics, drawing, singing and physical exercise.

97 J.G. [J. Grzegorzewski], Szkolnictwo, no. 10, pp. 175-176.

98 In his work, Grzegorzewski drew attention to this issue a number of times. This is confirmed in the description of a particular custom: "When children go to school for the first time, they bring the teacher a cloth with money bundled inside. The mother adds to this some food and says: here is our child (there follows the name) whom we bring to you for instruction. We are giving you meat, we are giving you everything; spare no effort and make of this child a decent human being. Then she turns to the child: now you have heard what I said and told the teacher. Let us now see what he will do", J. Grzegorzewski, Za Dunajem, pp. 155-156.

99 J.G. [J. Grzegorzewski], Szkolnictwo, no. 8, p. 312.

${ }^{100}$ In cities the school year lasted 10 months, whereas in the countryside it was shortened to 7-8 months so that children could help their parents with the harvest or vintage; ibid., no. 10, p. 172.

101 The situation changed only in 1909. 
Beyond all doubt, the astonishing concerted effort of Bulgarians who struggled for the independence of the Orthodox Church and worked for the development of education brought impressive results, which were well beyond expectations and unheard-of in other parts of Europe. In a relatively short time Bulgarian society was woken from a nearly complete apathy: Bulgarians became firmly attached to their national spirit and instilled with love of their homeland, a sentiment which was made manifest a number of times in the following period of their history.

The changes described above, however, would not have been possible had it not been for the characteristic features of Bulgarians, which Grzegorzewski qualified as "innate". The dynamic process of development of Bulgarian statehood was interrupted by the Turkish domination over Bulgarian territories. Bulgarian political elites were eliminated from social life, ${ }^{102}$ and, concurrently, the Bulgarian people were demoted to the rank of cost-free labour force for nearly five centuries. ${ }^{103}$ As a result, the task of continuing the historical tradition and sustaining the national spirit had to be undertaken by rural populace. People living in the countryside, however, were denied their rights and excluded from participation in social life; ${ }^{104}$ in the subsequent decades this situation held on and deteriorated, which led to apathy and a sense of helplessness. With time, these two sentiments, mentioned above and often emphasised by Grzegorzewski, motivated a large portion of the rural populace to look out for opportunities to adapt to the circumstances. For this reason, Bulgarian peasantry were little interested in political activity and hostile to the ideas of national self-determination which were becoming ever more widespread in the Balkans. The spirits were so low, as Grzegorzewski noted, that in the early nineteenth century, when various chetas of insurgents appeared in Bulgarian territories, "the rural communities and their leaders denounced [these groups] of their own accord to the Turks and exposed their own militants. At the time, they seemed to say: "We are not doing well, but it may be worse when the Turks decide to take revenge on us; do not make our fate even worse". ${ }^{105}$ These attitudes, however widespread, were not typical of the whole society and were contested, among others, by the so-called hajduks, i.e. people who were ill-treated by government officials or Turkish judicial system and fled into

102 Grzegorzewski, Stronnictwa, pp. 81, 773; Bułgarya pod jarzmem, no. 301, p. 12; K. Murzyński, "Serbia i jej przodownictwo", Niwa, 9 (1880), no. 124, p. 245.

103 Grzegorzewski, Za Dunajem, p. 79. At the same time the rural population suffered under the burden of a Draconian system of taxation, which increased gradually; ibid., pp. 79-82.

104 Grzegorzewski, Spółczesna Bułgarya, no. 3, pp. 531, 546; id., Za Dunajem, pp. 77-78. He wrote: "as is usual for all Muslims, they greatly valued their Mahometan faith and they considered only their coreligionists worthy to be called human beings; the unbelievers did not qualify for them as godly creatures, worthy to be treated in a humane manner. Hence their condescending attitude to Christians, hence the contempt for them, hence haughtiness and pride”, ibid., p. 83; see also: "Ze wsi i miast Macedonii i Starej Serbii", Świat Słowiański, 9 (1913), no. 1, p. 285; Bułgarya pod jarzmem, no. 301, p. 12.

105 Grzegorzewski, Za Dunajem, p. 143. 
the mountains, where they formed more or less numerous bands of guerillas. ${ }^{106}$ Initially, their actions could have been characterised as acts of personal revenge, but with time this movement ever more often served as a vehicle for the ideas of national self-determination and patriotism. These ideas strengthened the national spirit and motivated Bulgarian society to resist the occupiers. Opposing attitudes, by contrast, were represented by a group of affluent peasantry, the so-called chorbaji, who considerably grew in numbers in the first half of the nineteenth century. "People would bow to them, but they were despised, for they often sucked people's blood and sweat". ${ }^{107}$ Aiming to retain their social status, the chorbaji often converted to Islam and served as local officials of the Turkish judicial and fiscal apparatus. They were loyal to Turkish authorities and greatly helped them in suppressing the resistance of Bulgarian hajduks and, subsequently, the national liberation movements.

The apathetic attitude of most Bulgarians was caused by several factors. First of all, they had no faith in success in confronting the might of the Sublime Porte, and secondly, they feared the revenge and destructive actions of the Patriarchate of Constantinople, which they had experienced a number of times. ${ }^{108}$ The crucial factor at work was their "Orientalisation", much more pronounced than in other Balkan nations, which was a result of both the proto-Bulgarian colonisation and the geographical position on the ethnic-cultural borderland. For this reason, as Grzegorzewski observed, Bulgarians evinced "a substantial degree of this Oriental mysteriousness, features characteristic of eastern culture". ${ }^{109}$ That "Orientalisation" made itself evident not only in the way of behaving, but also in physionomic features - the stature and facial traits, which made them look in a way similar to that of Turks and Tatars, and in their clothes. ${ }^{110}$ "When you look at a Bulgarian, particularly when he is wearing a fez or has no headgear at all [...], you would be at a loss to tell whether you see a Turk or a Bulgarian". ${ }^{111}$ Bulgarians, just like Turks, distinguished themselves in the Balkans in that they had

106 Ibid., p. 98; id., Spółczesna Bułgarya, no. 3, p. 545, S. Ciszewski, Wróżda i pojednanie. Studium etnologiczne, Warszawa, 1900, p. 51, A. Zawilski, O wolność Bułgarii, Warszawa, 1979, pp. 18-19.

107 Grzegorzewski, Za Dunajem, p. 97.

108 Grzegorzewski, Spółczesna Bułgarya, no. 3, p. 540.

109 Ibid., no. 2, p. 201; id., Stosunki, p. 416.

110 Grzegorzewski wrote: "in fact, except for the north-western areas of the country [...] people in the country wear similar clothes as the Turkish peasant: leather shoes on their feet, at times fixed with a strap, and trousers (the sleeves are slim at the bottom, but grow baggy and puffed, drooping down at the back like a sack [...]. Their jackets are short, reaching only to the waist, often with sleeves cut through, sewn (just like the trousers) from a thick brown-coloured broadcloth known as $a b a$, or, it one was richer, from a yellow-brown shayak; both were hemmed or braided with black passementerie ribbons, the so-called gaytan. On the trousers, but beneath the jacket they wear a red woolen sash, at times even seven ells long and of such width that they wrap it several times around their waist", Grzegorzewski, Za Dunajem, pp. 182-184.

111 Ibid., p. 182. 
an innate stately demeanour, they walked and spoke slowly, were far from being abrupt in their manners and rarely roused to anger. They were also very prudent in their words and deeds, and known for their watchfulness and extreme circumspection. Other things in common for both nations were the simplicity in their everyday meals, abstinence from drinking alcohol, strict customs and exceptional care for the purity of body and soul. ${ }^{112}$ On account of these numerous affinities Bulgarians engaged in familiar relations with Turks to a much greater degree than other Balkan nations, but, as Grzegorzewski observed, "there was more calculation and compulsion in their behaviour as opposed to the abjection, opportunism and servility of Greeks". ${ }^{113}$ However, some differences existed, among which one should note in particular the hardworking attitude of Bulgarians, their frugality and the unrivalled tenacity in pursuing their goals. ${ }^{114}$ In the view of the Polish researcher it was just these features which had led the Bulgarians to prosperity and wealth, ${ }^{115}$ a phenomenon clearly observable in the years after the regaining of independence.

Bulgarian territories were situated in the periphery of the Ottoman Empire, which meant that they were treated as a buffer zone of sorts and a source of sustenance for the capital city. This attitude prevailed for most of the period of Turkish occupation and was particularly noticeable after the withdrawal of Turkey from active political engagement in European affairs in the late seventeenth century. For this reason, Bulgaria had been an almost exclusively agricultural province ${ }^{116}$ until the year 1878 and this situation remained unchanged also in the early years after the reactivation of Bulgarian statehood. ${ }^{117}$ The structure of Bulgarian countryside resisted substantial changes, while the common remains of the Turkish system effectively hampered the development of agricultural technology and influenced the quality of farming. ${ }^{118}$

112 Ibid., pp. 39, 187.

113 Ibid., pp. 184-185. Another factor which was important for close contacts between these nations was the knowledge of Turkish among the Bulgarians and of Bulgarian among the Turks: "Near the Danube, at the Black Sea shore and in southern Bulgaria Turkish is spoken not only by peasants, but also by women living in rural areas, whereas the Turks in western Bulgaria communicate in Bulgarian with the Bulgarians, for they know their language”, ibid., p. 177.

114 Grzegorzewski, Stosunki, p. 417. He mentioned the characteristic "great stamina, diligence and thrift of the Bulgarian people, unsurpassed in Europe in this respect and probably second only to the Chinese", id., Za Dunajem, p. 179.

115 Grzegorzewski, Za Dunajem, p. 39.

116 "Kronika", Świat Słowiański, 9 (1913), no. 1, p. 196; see also: M.I. Newbigin, Geographical Aspects of Balkan Problems in their Relation to the Great European War, London, 1915, p. 212; W.S. Monroe, Bulgaria and Her People, Boston, 1914, p. 288; W. Miller, Travels and Politics in the Near East, London, 1898, p. 440; D. Davis, Bulgarian Mission of the Methodist Episcopal Church, New York, 1906, p. 10.

117 Still at the beginning of the 20th century almost $85 \%$ of the population was working in agriculture; "Kronika", Świat Słowiański, 8 (1913), no. 1, p. 196.

118 Ibid., p. 196. 
With this in mind, the authorities of the newly independent Bulgarian state made efforts to improve the situation in the countryside, knowing that agriculture was a crucial element of the economic structure. An important element of these efforts was the distribution of land to peasants, which was made possible in 1880 after the introduction of agricultural reform. The reform provided legal framework for the hitherto impetuous process of taking ownership over the land from the Turks and Circassians who retreated en masse from Bulgaria. ${ }^{119}$ These actions stabilised the situation, but nevertheless the structural changes were limited. Smallholders were still dominant, ${ }^{120}$ and only about 55,000 farmers out of over 450,000 peasants had at their disposal acreages between 10 and 15 hectares. ${ }^{121}$ However, the increase in agricultural production, and consequently the prosperity of the inhabitants, instantly influenced the change in the look of both rural centres $^{122}$ and the cities which at the time were the main recipient of crops. ${ }^{123}$

At the core of agricultural production lay the cultivation of cereals: ${ }^{124}$ wheat, barley, oat, proso millet and spelt, as well as corn and rice. ${ }^{125}$ About $75 \%$ of the total acreage was reserved for cereals and the yield per year amounted to $30 \mathrm{mil}$ lion hectolitres of grain. ${ }^{126} \mathrm{~A}$ fair portion of the land, $c a 17,5 \%$, was reserved for the production of hay. Among other plants grown in Bulgaria the following species were seen as very important: broad beans, vine, fruits and vegetables ${ }^{127}$ such as watermelons and melons, cauliflower, squash, lentils and artichokes (the latter were widely known and highly appreciated on the European market). ${ }^{128}$ Another

119 Grzegorzewski, Za Dunajem, p. 323; Jireček, Geschichte der Bulgaren, p. 200.

120 A half of the farms were less than 30 decars in acreage, but $c a 1 / 4$ of these did not exceed 1 decar $\left(1\right.$ decar $=1000 \mathrm{~m}^{2}$ ); C.G. Popoff, La Bulgarie économique 1879-1911, Sofia 1920, p. 110; Newbigin, Geographical Aspects, p. 212; W.K. Weiss-Bartenstein, Bulgarien, Land, Leute und Wirtschaft zur Zeit des Balkankrieges, Leipzig, 1913, p. 177; see also: Monroe, Bulgaria and Her People, p. 289.

121 Grzegorzewski, Za Dunajem, p. 338; "Kronika", Świat Słowiański, 8 (1913), no. 1, p. 196. The land use tax in the amount of over 500 levs per year was paid by no more than 322 farm owners.

${ }_{122}$ Grzegorzewski, Za Dunajem, p. 351; "Kronika”, Świat Słowiański, 8 (1913), no. 1, p. 327.

123 Grzegorzewski, Stosunki, pp. 417-418; “Kronika”, Świat Słowiański, 7 (1907), no. 2, p. 192.

124 Monroe, Bulgaria and Her People, p. 289. The value of grain produced in Bulgaria was estimated to be at ca 340 million levs; "Kronika", Świat Słowiański, 8 (1913), no. 1, p. 196.

125 Grzegorzewski, Za Dunajem, pp. 318-319; “Recenzye i sprawozdania”, Świat Słowiański, 7 (1911), no. 1, p. 226.

$1261 \mathrm{hl}$ of grain $=c a 70 \mathrm{~kg}$.

127 Bulgarians mastered to perfection the art of growing vegetables and fruit. For this reason they were becoming respected specialists in this field not only in the Balkans, but also in the whole of Central Europe, including Galicia and Congress Poland, where they often travelled as the so-called itinerant gardeners. Grzegorzewski noted that every year 12,000 people were involved in this kind of work; Grzegorzewski, Za Dunajem, pp. 347-348.

128 "Recenzye i sprawozdania", Świat Słowiański, 7 (1911), no. 1, p. 227; see also: A. Piotrowski, "Z dziejów Carstwa Bułgarskiego. Wspomnienia osobiste", Tygodnik Ilustrowany, 42 (1908), p. 848; Monroe, Bulgaria and Her People, p. 289; Weiss-Bartenstein, Bulgarien, Land, Leute, p. 177; Jireček, Geschichte der Bulgaren, p. 176. 
important element in agricultural production was the cultivation of hemp, flax and roses. Even though the latter plant was grown on a mere $0,2 \%$ of the overall acreage, it was the most commonly cultivated plant in some regions. As Grzegorzewski noted: "from Plovdiv to the Rhodopes [...] there are swathes of land strewn with roses from Peshtera to Stanimaki; they look as if they were one infinitely extended rosy carpet. Another similar rose-growing region is in the southern Balkan and Sredna Gora, particularly in the Kazanlik and Karlov valleys; as we cultivate wheat and rye, they have fields filled with roses glowing onto the azure sky". ${ }^{129}$

The cultivation of roses provided the basic raw material for the production of rose oil, one of the most important export commodities of Bulgaria. ${ }^{130}$ The production of tobacco and cotton was not as important at the time. ${ }^{131}$ Apart from the growing of plants, a vital element of agricultural production was the breeding of animals. The most popular species was beef and dairy cattle as well as such draft animals as buffalos. ${ }^{132}$ To this one should add other livestock such as sheep (in the first years of the regaining of independence the estimated number of sheep was c. 7 million), goats, donkeys and poultry (in addition to chickens, the north-eastern regions were known for the breeding of pheasants). ${ }^{133}$ Bulgarian agriculture was in the process of intense development after 1878, which had a significant impact of the dynamic increase in state revenue owing to the new opportunities for exporting agricultural products. Nevertheless, in some regions the methods of agricultural production remained markedly primitive. ${ }^{134}$ For this reason Bulgarian authorities strove not only to interest peasants in the new forms of farming, but also persuade them to use agricultural machinery. ${ }^{135}$ On the one hand, these activities were a manifest sign of remarkable far-sightedness and great care for the crucial sector of economy, and on the other they responded to the opportunities of uninhibited trade with the whole world which were a result of the reactivation of independence.

129 Grzegorzewski, Za Dunajem, pp. 33-34.

130 The production of rose oil was very profitable. "A pound of this oil, when sold in wholesale trade, costs about 200 guldens, while a small battle costs 15-20 crowns, at best with an admixture of bergamot or geranium oil (pure rose oil is even more expensive)", Grzegorzewski, Za Dunajem, p. 332. It is worth noting, by way of comparison, that the revenue of Dzików commune in Galicia in 1872 was $198 \mathrm{zl}$ (guldens), while the communal scribe at the time earned $15 \mathrm{zł}$. (30 crowns) per year; J. Słomka, Pamiętniki włościanina, Kraków, [1929], pp. 166, 211; see also: Bezenšek, Bolgarija in Srbija, pp. 104-106; Przesmycki, Rumelia Wschodnia, pp. 425-426; Jireček, Geschichte der Bulgaren, pp. 180-181; Newbigin, Geographical Aspects, pp. 212-213; Miller, Travels and Politics, p. 444; Monroe, Bulgaria and Her People, p. 290; Weiss-Bartenstein, Bulgarien, Land, Leute, p. 177; J.F. Fraser, Pictures from the Balkan, London, 1906, pp. 93-99.

131 Grzegorzewski, Za Dunajem, pp. 327-328.

132 Ibid., pp. 337-338.

133 Ibid., pp. 35-36.

134 Recenzye i sprawozdania, Świat Słowiański, 7 (1911), no. 1, p. 227; Przesmycki, Rumelia Wschodnia, pp. 423-424; Jireček, Geschichte der Bulgaren, pp. 174-175; Monroe, Bulgaria and Her People, p. 288; Davis, The Bulgaria Mission, p. 12.

135 Grzegorzewski, Za Dunajem, pp. 341-343. 
As early as in 1879 , the total worth of goods imported to Bulgaria amounted to over 32 million levs, despite the fact described by Grzegorzewski, who noted that "Bulgarians are prejudiced and wary, or even disgusted with regard to foreigners; they are reluctant to buy their products". ${ }^{136}$ The worth of imported goods rose by $50 \%$ in the following year, and in 1881 it reached nearly 60 million levs. In spite of the contradiction with the aforementioned national feature, the import of goods was very rapidly noticed by the authorities who extended their supervision exercised by respective officials on account of the substantial income gained by the state from customs duties estimated at 3-5 million levs. ${ }^{137}$ Simultaneously, measures were taken to provide the citizens with access to all necessary products and ensure the supply of raw materials unavailable in Bulgaria for the growing industry. For this reason, in the years after 1878 salt was the most important commodity bought from abroad, imported mainly from neighbouring Romania for nearly 15 million levs per year. The following goods were also imported: yarns and cotton products (5.5 million), machinery and equipment (c. 4 million), Nuremberg $\operatorname{goods}^{138}$ (c. 2 million), sugar ( 2 million), as well as wool products, alcohol beverages, building materials, metal wares, tanned skins, coffee and other products. All in all, in the years 1880-1881 Bulgaria imported 72 types of products, mainly from Austria-Hungary, Great Britain, Turkey, Italy, France, Russia and Germany. ${ }^{139}$ Austria-Hungary was by far the most important trading partner of Bulgaria at the time. The goods imported from there belonged to 54 categories of products, including fabrics, machinery, alcohols as well as clothes and jewellery. This situation was influenced, on the one hand, by the increasingly more noticeable conception of loosening the ties between Bulgaria and Russia and seeking rapprochement with the western powers, an attitude represented by both Alexander Battenberg and the circles of Bulgarian bourgeoisie in the making. On the other hand, the attractive prices of the goods offered by Austria-Hungary was a major factor at play. ${ }^{140}$ This tendency, established in the first years after the regaining of independence, remained in force for several decades, until the outbreak of the Balkan wars in 1912, a fact foreseen by Grzegorzewski. ${ }^{141}$

Bulgarians are particularly keen for progress, which is taking place at an astoundingly quick pace. It was only a year after the congress of Berlin, which paved the way to Bulgaria for

136 Grzegorzewski, Stosunki, p. 418.

137 Ibid., p. 420.

138 The term "Nuremberg goods" was used with reference to small, hand-made accessories, toys and small household objects.

139 Grzegorzewski, Stosunki, p. 421.

140 Grzegorzewski wrote: "If in Filipopol or Sofia one can buy a pair of shoes from Vienna for 10-12 francs, while those produced in Russia or locally are sold for 20-24 francs, then the competition for higher prices is fairly difficult, even if other conditions of the product (such as the quality and durability) were on the latter side", ibid., p. 426.

141 Ibid., pp. 428-429. 
Europe, when the country began to undergo a metamorphosis as if touched with a magic wand: the cities changed their physiognomics and people changed beyond recognition by getting rid of their customary attire and changing it into European dress, by acquiring new needs and new conditions of life $\left[\ldots . .{ }^{142}\right.$

As a result, Bulgaria entered the path of modern development, a process which, as illustrated above, secured its place in the forefront of the countries of the region and made it an important partner on the European scale. This would not have been possible without the national awakening, consistent and concerted effort and the reasonable political actions of the consecutive Bulgarian governments. Had it not been for the work of Jan Grzegorzewski, an eminent expert on Bulgaria and a true lover of the Bulgarian people, the study of this process and examining its course from Polish perspective would be undoubtedly greatly impeded.

\section{Abstract}

The seizure of the Bulgarian lands by the Turks at the end of the $14^{\text {th }}$ century brought up many deep and multifaceted changes for the Bulgarians. It marked the end not only of their flourishing state, which at times had counterbalanced the Byzantine Empire, but mainly of their political elites which would provide the foundations for their struggle for independence. For this reason, with the lapse of time, Bulgarian rural population, burdened with draconian obligations and pushed aside on the margin of social life, sank deeper and deeper in apathy, growing in impotence. A change in the situation occurred only at the turn of the nineteenth century, when a process of national revival began in the Bulgarian lands. Not only did the process revive a national spirit in the Bulgarians and motivate them to fight, but also filled them with a sense of dignity, which made it possible for them soon after they regained independence to place their country at the lead of the region. Those dynamic changes were observed by the outstanding and excellent Polish Slavic philologist and Orientalists Jan Grzegorzewski during his voyages throughout the Bulgarian lands; all his observations and impressions he described in several books and essays published in popular papers and periodicals. The image of Bulgaria of the end of the nineteenth century has been still a valuable source of information both for historians and for other scholars.

\section{Bibliography}

Bezenšek A., Bolgarija in Srbija, Celovec, 1897.

"Bułgarya pod jarzmem tureckim", Niwa, 16 (1887), nos. 301, 302.

Chłoniewski A., Nieśmiertelni. Fotografie literatów lwowskich, Lwów, 1898.

Ciszewski S., Wróżda i pojednanie. Studium etnologiczne, Warszawa, 1900.

Czarnowski S.J., Dziennikarstwo słowiańskie i polskie, Kraków, 1895.

Davis D., The Bulgaria Mission of the Methodist Episcopal Church, New York, 1906.

Dobosz K., "Początki i pierwszy tom Rocznika Orientalistycznego. Przyczynek do dziejów czasopisma”, LingVaria, 7 (2012), no. 2.

142 Ibid., p. 428. 
Fraser J.F., Pictures from the Balkans, London, 1906.

Grzegorzewski J., Albania i Albańczycy, Lwów, 1914.

G[rzegorzewski] J., "Dragan Cankow”, Świat Słowiański, 7 (1911), no. 1.

Grzegorzewski J., "Dwa fermany sułtańskie z XVIII w. Zarys historyczny traktatów handlowych Polski z Turcyą, Rocznik Orientalistyczny 1916-1918.

G[rzegorzewski] J., "Echa zjazdu sofijskiego", Świat Słowiański, 7 (1911), no. 1.

Grzegorzewski J., "Ein türk-tatarischer Dialekt in Galizien: Vokalharmonie in den entlehnten Wörtern der karaitischen Sprache in Halicz", Sitzungsberichte der Kaiserlichen Akademie der Wissenschaften Philosophisch-Historische Klasse, 146 (1903), Abh. 1.

Grzegorzewski J., "Ferman sułtana Abdulhamida I z r. 1775”, in: Księga pamiątkowa ku uczczeniu czterdziesto-pięcioletniej pracy literackiej prof. dr Józefa Tretiaka, Kraków, 1913.

Grzegorzewski J., Grób Warneńczyka: badania autentyczności grobu przy 4-tym kilometrze pobojowiska warneńskiego $z$ d. 10-go listopada 1444 r., z 14 załącznikami, Kraków, 1911.

Grzegorzewski J., Jezyk Łach-Karaitów. Narzecze południowe (łucko-halickie), Kraków, 1917.

Grzegorzewski J., Na Spiszu. Studya i teksty folklorystyczne, Lwów, 1919.

G[rzegorzewski] J., "O 'Echa zjazdu sofijskiego"', Świat Słowiański, 7 (1911), no. 1.

Grzegorzewski J., "Penczo Sławejkow”, Świat Słowiański, 8 (1912), no. 2.

Grzegorzewski J., "Rok przewrotów (Bułgarya 1885/6)”, Lwów, 1900.

Grzegorzewski J., “Siedmiomiesięczna walka o samoistność Bułgaryi”, Świat Słowiański, 8 (1912), no. 1.

Grzegorzewski J., “Spółczesna Bułgarya”, Ateneum, 8 (1883), vol. 2, nos. 2, 3.

Grzegorzewski J., "Stosunki handlowe z Bułgaryą", Przegląd Powszechny, 4 (1887), no. 1.

Grzegorzewski J., “Stronnictwa bułgarskie po przewrotach”, Świat Słowiański, 8 (1912), no. 2.

Grzegorzewski J., "Stronnictwa bułgarskie za Aleksandra Battenberga”, Świat Słowiański, 7 (1911), no. 2.

J.G. [J. Grzegorzewski], “Szkolnictwo w Bułgaryi”, Przegląd Powszechny, 4 (1887), nos. 8, $10,11$.

Grzegorzewski J., Za Dunajem (Bułgarya, Serbia, Czarnogóra), Lwów, 1904.

Grzegorzewski J., Z kresów Połabskich, Kraków, 1885.

Grzegorzewski J., Z sydżyllatów rumelijskich epoki wyprawy wiedeńskiej akta tureckie, Lwów, 1912.

Hołubowicz J., Bułgarya, jej przeszłość dziejowa i jej obecne narodowe i religijne odrodzenie, Kraków, 1885.

Hoszowska M., Ludwik Finkel i Akademia Umiejętności. Z dziejów współpracy naukowej Lwowa i Karkowa na przełomie XIX i XX wieku, Rzeszów, 2011.

История славеноболгарская, Sofija, 1961.

Jankowski C., Na gruzach Turcji. Zarysy polityczno-publicystyczne, Warszawa, 1915.

Jireček C., Geschichte der Bulgaren, Praga, 1876.

Kaczmarek U., “Jan Grzegorzewski - 'pierwszy' polski orientalista”, Sprawy Wschodnie 2002, no. 1.

Kaczmarek U., "Wystawa poświęcona prof. Tadeuszowi S. Grabowskiemu i prof. Janowi Grzegorzewskiemu, Sofia, 24 czerwca 1996”, Etnografia Polska, 41 (1997), nos. 1-2.

Каравълчев В., “Холмската мисия на Йосиф Соколски и краят на Брест-литовската уния”, Християнство и култура, 9 (2011).

Каравълчев В., “Някои бележки върху личността на първия униатски архиеп. Йосиф Соколски”, Християнство и култура, 7 (2011).

Kizilov M., "Jan Grzegorzewski's Karaite materials in the archive of the Polish Academy of Sciences in Kraków", Karaite Archives, 1 (2013).

Klejn Z., "Polskie stronice w bułgarskiej historii", Mazowieckie Studia Historyczne, 2 (1998).

Klejn Z., Polskie ślady w budowie nowożytnej Bułgarii, Łowicz, 1999. 
Манафова Р., “Културното развитие на България при временното руско управление (1877-1879)", in: Известия на Института за история, т. 29: Из историята на българската наука, просвета и култура през ХІХ и ХХ в., 1986.

Miller W., Travels and Politics in the Near East, London, 1898.

Monroe W.S., Bulgaria and Her People, Boston, 1914.

More R.J., Under the Balkans. Notes of a Visit to the District of Philippopolis in 1876, London, 1877.

Murzyński K., “Serbia i jej przodownictwo”, Niwa, 9 (1880), no. 124.

Newbigin M.I., Geographical Aspects of Balkan Problems in their Relation to Great European War, London, 1915.

Piotrowski A., "Z dziejów Carstwa Bułgarskiego. Wspomnienia osobiste”, Tygodnik Ilustrowany, 42 (1908).

Popoff C.G., La Bulgarie économique 1879-1911, Sofia, 1920.

Przesmycki Z., "Rumelia Wschodnia", Ateneum, 10 (1885), vol. 4.

Reychman J., "O wykorzystanie źródeł orientalnych do historii Polski”, Przegląd Historyczny, 58 (1967), no. 2.

Reychman J., Peleryna, ciupaga i znak tajemny, Kraków, 1971.

Reychman J., "W ośrodkach orientalnych i orientalistycznych Bułgarii", Przeglad Orientalistyczny, 21 (1957), no. 1.

Reychman J., "Zasługi Jana Grzegorzewskiego na polu zbliżenia kulturalnego polsko-bułgarskiego", in: Stosunki literackie polsko-bułgarskie, ed. J. Śliziński, Wrocław, 1971.

Rubacha J., "Obraz przemian politycznych w Bułgarii w książce Jana Grzegorzewskiego Rok przewrotów. (Bułgarya 1885/6)”, in: Wokół reportażu podróżniczego, ed. D. Rott, Katowice, 2007.

Rubacha J., Malinowski A., Giza A., Historia Bułgarii 1870-1915. Materiały źródłowe z komentarzami, Warszawa, 2004.

Sława T., "Propaganda unicka w Bułgaryi”, Świat Słowiański, 9 (1913), no. 2.

Słomka J., Pamiętniki włościanina, Kraków, [1929].

Sopodźko T., "O czasopismach w Bułgaryi”, Przegląd Powszechny, 8 (1891), no. 29.

Stacya naukowa polska na Wschodzie Hyacinthaeum, Warszawa, 1916.

Świat Słowiański, 3, 7-9 (sections: "Kronika", "Przegląd prasy słowiańskiej”, "Recenzje i sprawozdania").

Tyszkiewicz J., “Jan Grzegorzewski w ostatnich latach życia: 1916-1922”, Almanach Karaimski, 4 (2015).

Wegnerowicz W.R., “Odrodzenie Bułgaryi”, Literatura i Sztuka. Dodatek do Dziennika Poznańskiego, 48 (1912).

Weiss-Bartenstein W.K., Bulgarien, Land, Leute und Wirtschaft zur Zeit des Balkankrieges, Leipzig, 1913.

Zawilski A., O wolność Bułgarii, Warszawa, 1979.

Zankow S., Die Grundlagung der Vefassung der bulgarischen orthodoxen Kirche, Zürich, 1917.

Zborowski J., "Historia pewnej książki. Wspomnienie o Janie Grzegorzewskim", Rocznik Podhalański, 5 (1992).

“Ze wsi i miast Macedonii i Starej Serbii”, Świat Słowiański, 9 (1913), no. 1.

Jaroslaw Rubacha, dr hab., historian of the Balkans, employed in the Institute of Journalism and Social Communication at the University of Warmia and Mazury in Olsztyn; his research interests include the history of the Balkan Peninsula in the nineteenth and twentieth centuries, the history of Bulgaria and Polish Slavophilism in the early twentieth century (j.rubacha@wp.pl). 